\title{
10. Hank of Coombs
}

\author{
Brij V. Lal
}

Brij V. Lal is professor of Pacific and Asian History in the School of Culture, History and Language, College of Asia and the Pacific at The Australian National University. He was Hank's colleague in the Coombs Building for 20 years.

Hank was a name before I met him in the flesh. I was in the Coombs tea room when I looked up to see a man slowly making his way down the stairs. 'Dr Nelson', I said. 'G'day', he boomed, this tall, modest, unglamorous, even laconic man with a drooping 'Henry Lawson' moustache; 'the name is Hank'. And so he remained for me for the next 20 years, and for countless others: an iconic figure, an authentic, down-to-earth Australian, not an American with a broad Australian accent, as his name seemed to suggest. Boort, Hank's birthplace, is in north-western Victoria on the edge of the flat, red-brown Mallee country of dead sheep, frequent droughts and interminable distances, and he casually presented himself to visitors as nothing more than an ordinary 'boy from Boort' in perpetual wonderment in the august halls of the academy. But no one was fooled. Behind that unselfconscious country-lad façade was a sharp, shrewd intellect with practical understanding of the ways of the real world and a deep appreciation of the vagaries of the human condition. As a guide in fair weather and foul, there were few to equal his skills. As teacher, writer, scholar, administrator, supervisor, colleague and encourager, Hank was one of a kind.

Hank had been in the Coombs Building for 17 years when I joined in 1990, his reputation solid as the world's leading historian of Papua New Guinea. He died with that reputation intact. But Hank was more than just a great scholar, of whom there was no shortage in the Coombs. He was to many younger colleagues a generous mentor and a kindly presence, a guide and a tutor as well. He was my closest colleague for much of our time together in Coombs, and he opened many a window for me on the land he loved so passionately.

At the most personal level, he introduced me to the intricacies of Australian sporting culture gradually over the years. This he did for others as well, including foreign academic visitors perplexed by the arcane rules of cricket or the incredible athleticism of Aussie Rules players in tight-fitting jerseys and short shorts. I have never been able to follow the rules of the latter despite Hank's best efforts to teach me. The Coombs tea room served as the tutorial venue. One Monday morning, following long-established ritual, Barry Smith, another distinguished denizen of Coombs, and Hank were talking Aussie Rules at morning tea when, very new to Australia, I inadvertently blurted out, 'Ah, is 
that the game they play in the southern states?' Barry looked at me straight in the eye and said with mock menace: 'You Third World fool, you. Aussie Rules is not a Victorian game. It is the Australian game, and don't you ever forget it'.

On the way back to our offices, feeling suitably chastised and slightly embarrassed at such elementary ignorance, I asked Hank the reason for Barry's belligerence, or pretended belligerence. 'Cast an eye of pity on Barry', Hank said, gently smiling. 'He is a Victorian'. And a Hawthorn man, as I later discovered, like the great Monash historian Geoffrey Serle, who once famously declared: 'I am an Australian and a Hawthorn man. Stuff Victoria and Melbourne'. ${ }^{1}$ This from a bloke who wrote a two-volume history of Victoria in the 19th century! ${ }^{2}$

Hank did not have a favourite football team, Jan tells me, unless it was Boort playing in the North Central Football League. Then he barracked for it fullthroated. Otherwise, he would decide which team he wanted to win after watching the game for the first five minutes. No wonder he got on well with all and sundry in the university's football community. Hank was a proud Victorian but not one to impress his attachments and interests on others, unlike so many from that part of the world who were (and are) defiantly different, and casually indifferent to outside opinion about themselves.

Hank tutored me and many other newcomers to Australia in the country's literature and scholarship. I had read at school and at university in Fiji novels by Patrick White (Voss) and Randolph Stow (To the Islands, Tourmalin), which rather surprised and impressed Hank: these books, at that time, in that remote, colonial backwater. 'The Poms did do some things right, and you are a living proof of it, mate', Hank used to say to me. He introduced me to many newer Australian authors I did not know, such as Robert Drewe (Shark Net, The Body of Contented Men).

Australian novels or novels about Australia were Hank's passion. Sitting in a doctor's waiting room killing time in Sydney during one of his frequent forays there in the last years of his life, Hank read most of Peter Carey's Parrot and Oliver, and he emailed me: 'He writes sharp, smart prose. It was good to be immersed in his art'. Hank was like that: he read widely and shared his passion with those he knew cared for books and good writing. I still have with me a second-hand copy of Margaret Kiddle's Men of Yesterday that Hank gave me. It has this magical opening sentence: 'Once, in the land men now call the Western

\footnotetext{
1 John Thompson, The Patrician and the Bloke: Geoffrey Serle and the Making of Australian History, Canberra: Pandanus Books, 2006, p. xvii.

2 Geoffrey Serle, The Golden Age: A History of the Colony of Victoria, 1851-1861, Parksville: Melbourne University Press, 1963; The Rush to be Rich: A History of the Colony of Victoria, 1883-1889, Carlton: Melbourne University of Press, 1971. Later, Serle turned to writing biographies, including one of General John Monash, as well as a cultural history of Australia.
} 
District of Victoria, the mountains touched the clouds and from their summits fire sprang forth' ${ }^{3}$ Hank knew that world well. His master's thesis was on missions and Aborigines in western Victoria.

I suppose the gift of history books was also Hank's way of telling me what he thought good history writing was, or should be: literate and literary, composed with flair and imagination. The last big book he read before he died was Bill Gammage's The Biggest Estate on Earth. ' 'It is brilliant', he said to me as he lay stricken in bed at Claire Holland Hospice by Lake Burley Griffin in Canberra. He would not have been surprised at all, but rather much pleased, to see it win a clutch of big prizes in Australia. And one of the last books we discussed over morning tea before Hank left Coombs for good was Jim Davidson's life of the historian Sir Keith Hancock, A Three-Cornered Life. ${ }^{5}$ A day later, Hank wrote to me:

I meant to make a further point about the Davidson biography of Keith Hancock. He deals well with a couple of incidents when Hancock as director or head of department was confronted with intractable and perhaps either mentally obsessive or disturbed colleagues: Lindsay and Ellis. I know little of the Ellis story and nothing of Lindsay. These are salutary stories. I concluded that I had been relatively lucky in my undistinguished administrative career. I trust that you never encounter a Lord Lindsay.

I did not, and now nearing retirement, do not expect to.

In his farewell speech organised by the Division of Pacific and Asian History on 24 August 2011, Hank remarked with characteristic generosity: 'With Brij, I enjoyed many conversations in this tea room about two important topics: cricket and good prose'. Cricket was certainly our mutual passion, and it featured in many of our conversations. It featured in the farewell party we hosted to mark Hank's retirement. He drew up the invitation list himself for a party in the Pavilion of the China Tea Club at the close of play on Thursday November 28, 2002'. The batting order would be as follows: Amirah Inglis (left-handed), Keith Willey (right-handed), Ken Inglis (selector), John Waiko, Bill Gammage (captain), August Kituai, Ian Willis, Tim Bowden, Jude Shanahan (keeper), Gavan Daws (selector), Keiko Tamura, Daniel Oakman (night watchman). Commentary: Professor Donald Denoon; Presentation of Awards: Professor Brij Lal; Man of the Match: Professor Hank Nelson; Best and Fairest: Professor Hank Nelson; Modest Acknowledgment: Professor Hank Nelson. 'Stumps'. Sad word that, when you think about it, signalling the end of play and metaphorically of

3 Margaret Kiddle, Men of Yesterday: A Social History of the Western Districts of Victoria, 1834-1890, Carlton: Melbourne University Press, 1961, p. 3.

4 Bill Gammage, The Biggest Estate on Earth: How Aborigines Made Australia, Sydney: Allen \& Unwin, 2011.

5 Jim Davidson, A Three-Cornered Life: The Historian WK Hancock, Sydney: UNSW Press, 2010. 
life itself until, if you are lucky, a new beginning the next day. All this says as much about Hank's passion for the game as it does about some of the people in Canberra who mattered to him - and to whom he mattered. Such playfulness, such innocent fun, speaks to life in the academy of another era - when time was found for serious matches between academic departments, when perfectly sensible people took time off to watch an engrossing day of play, when 'What's the score?' needed no further explanation.

Hank's advice about good prose: certainly. He himself wrote 'crisp, clear sentences in the unaffected language and accents of common Australians', as one anonymous observer put it. He wrote with the patience of readers in mind, and it is no surprise that his books were very well received by the wider reading public and are still in print, to the quiet envy of some of his colleagues whose eyes and energies were more focused on the verdict of their fellow professionals in the cloistered halls of the academy. Many people in the department sought the service of Hank's editorial pen, or rather, pencil.

I was no exception. Hank read most things, certainly nearly all the smaller pieces, that I wrote over the last decade or more. He would return the text with pencil marks in the margin: ticks for the phrases and paragraphs he liked and suggestions for revision where there was opaqueness and ambiguity. Stewart Firth remarks that with Hank, 'no request for comment on a manuscript was turned down', and he never stinted his time. 'He always encouraged others in the field, seeing them as co-workers rather than as competitors, and, best of all, returned manuscripts promptly'. 'Prompt and helpful' are the words Doug Munro uses to describe Hank's responses to his queries as review editor of the Journal of Pacific History. Perhaps promptness was a habit Hank had picked up from his days of high school teaching, for few academics I know are ever prompt.

Hank gave me two pieces of writing advice that have served me well. 'Shorter sentences, mate, shorter sentences', he would say whenever he came across a meandering three- or four-line clunker in my prose. And 'avoid "however": a lazy writer's word'. I have avoided however ever since. 'I am in despair in our misuse of the language when I read an opening such as this', he once wrote to me about a submission to a scholarly journal that he had been asked to read: 'Imbricated histories are evident in the work of Australian filmmakers in Papua New Guinea, through contestations and shifts in the documentary practices that mediate the visual archive constituted by such work over the last century'. He continued: 'I started rewriting it, changing "Imbricated" to "Overlapping", "contestations" to "contest", and "constituted by such work" to "made", but then decided I did not know what the sentence was trying to say anyway". All this was so unnecessary: 'Mystifying vocabulary and sentence structure 
are all the more regrettable where the writer has clearly done a lot of research and could tell us something new and interesting'. Hank is right. If an author is asking his or her reader to work that hard, it had better be well worth it.

Hank always had a bee or three in his bonnet about bad prose. Once, upon reading an impenetrable, obfuscatory passage by a person being considered as a panel member of a research review committee for our school, Hank wrote to Robin Jeffrey, Dean of the College of Asia and the Pacific: how could a scholar with this kind of prose be allowed to have anything to do with the research school, to come anywhere near it, Hank implied in his message. The passage Hank quoted had some choice gobbledygook such as 'the fixation of speech through inscription', 'the indexicality of the performance and moves away from the dialogical situation', 'metadiscursive notions', 'the intertextual world which are not the culture as texts', 'the flow of substances between different generations or domains of the universe'. 'I am keeping an open mind', Hank informed Robin, tongue-in-cheek. Robin wrote back acknowledging Hank's fine-tuned radar for detecting academic weasel-words: 'Keep on keeping the mind open'.

Supervision is an integral part of the life of a research professor, and Hank had his share of graduate students during his time at ANU. Good supervisors know that students come from varying backgrounds and levels of training in their disciplines, and they have their own needs and requirements. One size does not fit all. Hank understood this better than most, open, democratic and tolerant of a wide range of views, encouraging his students to reach their own conclusions based on thorough assessment of evidence with all its contradictions. Klaus Neumann says his relationship with Hank was 'based on mutual respect'.

At no time did he attempt to make me follow his lead, make me adopt his assessment, or steer me towards his own way of approaching the Papua New Guinean past. He pointed out flaws in my arguments and never held back any criticisms, but he let me find my own way. He would closely read what I had written and listen attentively to what I said, and respond by asking questions and not passing judgments.

Still, Klaus says that 'from him I learnt more about writing Pacific Islands' history than from anybody else'.

August Kituai, from Papua New Guinea, agrees. 'He provoked me into discovering my strengths and predilections, and into persevering with unorthodox ideas'. He found Hank caring, supportive and encouraging. August's two years of fieldwork in Papua New Guinea were successful, he says, 'because it was accompanied by an extensive correspondence' with Hank. August also picked up from Hank something of the art and technique of writing cross-cultural history. He was 
'most struck by his ability to listen sensitively to Melanesians and Europeans talking to him, which translates into a "gentle" rendering of people's memories into writing'. Hank's writings lack 'explicit theoretical reflections', yet, August continues, 'through his poetics of history he ponders about issues that would be absent from any theoretical historical narrative'. August thought both Hank's 'respectful treatment of the subjects of his writings, and his reflectivity, are aided by, if not an outcome of, his admirable use of the English language'. Respectful treatment in Hank's case meant, among other things, concern for the place of common people in history, using seemingly small and insignificant incidents to see wider trends about the operation of power in small-scale societies, for instance, or to consider why certain imported institutions worked in developing countries and others did not. 'In many ways, you are an unsung hero', August said, 'but knowing a little about you, that is how you prefer to be'. Lookim yulong sampela taim, wantok.

Hank was a conscientious examiner of theses and dissertations. A good thesis needed little commentary, he used to say to me; it was the weak ones that did. In these instances, he would produce several single-spaced pages of corrections and advice on revision. I know that sometimes he took a week to examine a thesis. I don't know if the examinees knew how lucky they were to have Hank's detailed comments. He was sufficiently concerned about the ethics and practice of dissertation examining in history in Australia to write an informed survey piece on the subject:

The PhD examiners are gatekeepers. The candidates come up to the gate, two men for every woman. One man takes his thesis from under his arm, and presents it to the three gatekeepers. The candidate waits, shifting from foot to foot. He is called forward, and told to go through the gate; or make changes on the spot; or go away, alter his thesis and try again; or go away and never come back. The gatekeepers are keepers of standards: standards of a discipline, a profession, an institution, and the national and international standing of a $\mathrm{PhD} .^{6}$

Throughout the 1990s until his retirement, Hank carried more than his share of administrative responsibilities at several levels. He served as the associate director of the Research School of Social Sciences in the mid-1990s when he was on secondment there for a couple of years. He served as the associate director of the Research School of Pacific and Asian Studies in the early 1990s and subsequently as convenor of the Division of Pacific and Asian History. After retirement, he served as chair of the State, Society and Governance in Melanesia Program. Hank did not actively seek administrative work for its own sake. He was

6 Hank Nelson, 'The Gatekeepers: Examining the Examiners', Australian Historical Association Bulletin 68 (1991), p. 12. 
first and foremost a scholar and a writer, who performed administrative duties out of a sense of obligation and perhaps also as a collective insurance policy. On those committees on which I served with Hank, representing our division or our school to the outside, Hank's modus operandi was clear. The brief had to be properly mastered and effectively defended in crisp, clear sentences. If the issue at stake was critical, prior networking helped. The mood of the meeting had to be properly judged. If the prospect of success was negligible, a strategic retreat had to be struck rather than expending capital on a foregone conclusion. There was no residual bitterness towards opponents but a strong determination to live to fight another day. Putting it another way, you can carry only so much powder and shot, so it is best to keep it for attainable ends.

Research and writing and teaching were the main game in academia, Hank always believed. Whenever he saw my name on yet another committee, he always said, 'No one will remember the committees you sat on, mate. They will remember the words you have written'. Hank's advice recalls the wisdom of Winston Churchill: words are the only things that last forever. Some administrative duties had to be done, Hank agreed, but he was particularly saddened by the strategy of some early career academics to advance their promotion prospects through committee work. Like Hank, I belonged to the older school about the proper vocation of scholars, though I also understand the enormous demands the academy makes on the time and energy of people now, demands not necessarily related directly to academic work, especially on women who are dragged to sit on endless committees in the interest of 'gender balance'.

Hank was not a micromanager. He had the big picture laid out and let his staff manage the day-to-day affairs of the department or division.

I soon learnt that the less I did the more smoothly the department ran. My laziness triumphed over my humility. I chaired meetings, sat on committees, and graciously stood aside from the detail of running the department. I less graciously accepted praise for the running of the department.

There was no sense of hierarchy in relationships, scant regard for protocol, and everyone addressed each other by their first names. Throughout the 1990s, the Division of Pacific and Asian History had a wonderful group of administrators, the best, bar none, with whom I have worked: Dorothy McIntosh, Marion Weeks, Jude Shanahan, Julie Gordon, Oanh Collins and Jenny Terrell, all now retired. With their complementary skills, they nurtured a real sense of community in the division that made working in it a distinct pleasure.

Hank's comments on each of them would ring true to all those who were in the division in those years. Marion Weeks gave 'excellent pastoral care' to doctoral students and beyond that 'gave aid and advice on formatting, printing and 
editing theses. In retrospect, she earned an honorary $\mathrm{PhD}^{\prime}$. Julie Gordon was the department's 'cheerful hospitality staff member', keeping a tab on 'who was having or fathering babies, having a significant birthday, publishing a book, being promoted, leaving or arriving, gaining a $\mathrm{PhD}$, going to hospital'. Before anyone knew it, Julie had bought a card or arranged to send flowers. Jude was the resident artist, designing 'several of the best books to come out of the department'. Oanh was the early bird of the department and known and admired for her legendary efficiency. 'I would sometimes bring in some typing for her to do', Hank remembered. 'I would say to her: "There was no hurry. Just attach it to an email when it's finished". Then I would race down the corridor to see if I could beat it to my desk. Often I failed'. Jenny held the Journal of Pacific History together for 40 years with tact and skill, succeeded admirably by Vicki Luker.

And then there was Dorothy. 'She was our boss', Hank said, borrowing my earlier description, a fortress of rectitude never breached. 'She never raised her voice, never looked under stress, never demanded deference'. Hank recalled something that would be familiar to most of us who at one time or another acted as head of department.

Sometimes I would be at home and Dorothy would ring to explain that there was a visitor claiming to have an appointment or that there was a meeting about to begin. There was no reprimand in her voice. My reply was always the same: 'Right, I will be there in ten or twelve minutes'. This had happened so often we both knew the time. When I arrived the visitor would be calmly sitting in the Records Room or Dorothy would have gathered the papers she thought I needed for the meeting.

Those days of easy camaraderie in the corridors of Coombs, the sense of being in it together, are a distant and vanishing memory.

Hank came to ANU with his reputation as the pioneering scholar of Papua New Guinea history cemented, though he remarked with typical bemused humility that since there was a rarity of Australians in the ranks of historians in the Coombs, his appointment had to do with affirmative action. He was the 'father of Papua New Guinea historiography', Donald Denoon wrote, a person who almost singlehandedly, and always with great modesty, created a new field of study. This was a rare achievement, recalled Bill Gammage, 'for few men have the opportunity to "create" the history of a country, and fewer still do it well'. His publications attest to the range and productivity of Hank's scholarship. His early work was solidly focussed on Papua New Guinea itself, with the behaviour, beliefs and policies of Australians there, with the experience of those who fought in World War II or were caught up in it, with the spread and efforts to control the disease kuru. 
Hank was partial to Papua New Guinea and Papua New Guineans, some people said, not always approvingly - meaning that he cared rather less about other parts of the Pacific. Hank was undoubtedly partial towards PNG. His love for the country and its people was deep and genuine and his disappointment with its many missed opportunities real. His affection clearly showed in his fluent Tok Pisin conversations with visiting Papua New Guinean politicians, civil servants and students, many of whom he knew very well. His young family had lived in Port Moresby from 1966 to 1972, he began his academic career there, and he wrote prolifically about its past and present. Hank's knowledge of other parts of the Pacific was less direct, less personal, more derived from secondary reading and detached, vicarious observation, but that would broadly be true of most people I know working on the region. It is certainly true of me. The Pacific world is simply too vast and too complex for one person ever to know its many subparts intimately. We acquaint ourselves with some small part of it and learn about the rest by osmosis.

So, yes, Hank was partial, but not parochial. He was well up on broader Pacific regional history, current on political developments in the region, Fiji in particular. He read and commented on submissions to the Journal of Pacific History on a range of topics. He supervised dissertations on non-PNG topics: on the Colombo Plan by Daniel Oakman, for example, or on Pacific regionalism by Sujatmiko, while serving on numerous other supervisory committees. He was up on Francis Fukuyama $^{7}$ and on the burgeoning literature on 'failing states', which some observers thought Melanesian nations were on the verge of becoming. Hank frequently cautioned against large perilous comparisons over time and space. Theory had to emerge from concrete experience closely observed.

Hank also wrote fine books on rural Australian one-teacher schools and life generally (With Its Hat about Its Ears) and on Australians in the Bomber Command (Chased by the Sun). Then there was a book, co-authored with Gavan McCormack, on the Thailand-Burma Railway, launched by Prime Minister Paul Keating and translated into Japanese, which greatly pleased Hanku-san. Towards the end of his career, Hank reflected obliquely on how he might wish to be remembered as a scholar of history, what he had tried to do, the approaches he had used.

\section{I like to take a perspective from somewhere in the Coral Sea, looking north and south, explaining Papua New Guineans to Australians, Australians}

\footnotetext{
7 An American political scientist and author of The End of History and the Last Man (1992), who argued that the triumph of Western liberal democracy may turn out to be the final form of government. Later Fukuyama turned his attention to the problems of small states, including those in Melanesia, in which context he visited Australia, where Hank met him.
} 
The Boy from Boort

to Papua New Guineans, Australians to Australians, but not completing the reflections by trying to tell Papua New Guineans about Papua New Guineans.

Hank moved between two seemingly disparate fields of research with consummate ease. Ken Inglis remarked on the uniqueness of Hank's strength. 'Scholars of Australian history', Ken said, 'tend not to be well acquainted with work on the Pacific, and vice versa; only observers familiar with both fields are well placed to recognise the scope of Nelson's work' ${ }^{8}$ For Ken, Hank 'displayed most impressively the quality which the late great W.K. Hancock characterised as span, both by moving between Melanesian and Australian history and by working in other media as well as print'. Greg Dening, himself a cultural mediator and boundary crosser of great distinction, concurred. Hank, he said,

has been for some years the most prominent Australian academic in mediating the complex and sensitive intercultural part of Pacific history. He has done this with innovative methodologies and by exploiting the widest possible range of media for such a history.

Further, Hank had 'taken the more difficult task of engaging himself in modern and current Pacific history, where the sensitivities are alive and strong'. And Greg made the point that Hank realised the audience of such histories had to be much wider than a handful of academics.

With equal ease, Hank moved between the past and the present. Much of his work on Papua New Guinea during his last years was on the contemporary affairs of that country. Alan Gilbert, who taught with Hank at the University of Papua New Guinea in 1967 and went on to become the vice-chancellor of Melbourne and Manchester universities, wrote perceptively that Hank showed an "awareness of the "great themes" underlying the particularities of time and place with which individual historians are concerned, and a profound sense of the importance of the past as a means of understanding the present'. This distilled understanding was communicated to the larger public in a variety of ways. As Hank said, 'While working in universities I have written for newspapers and magazines, done radio interviews and talked to journalists who have rung me on various matters'. In one year alone, just as an example, he gave interviews on violence in the Highlands of PNG, secession on Bougainville, the bombing of Darwin, the experience of prisoners of war, the fall of Singapore and themes in Australian nationalism.

Many of his articles in his last years came out as working papers for the State, Society and Governance in Melanesia Program. They were read by scholars and practitioners of policy alike and quickly made available online, whereas

8 In recent years, Peter Hempenstall and Clive Moore have moved assuredly between Australian and Pacific history. 
publishing in 'learned journals' - a quaint phrase, if ever there was one - could well take a long time and then reach only a miniscule audience. Hank published where he wanted to, to be read rather than just to get ahead. He had nothing left to prove, no further academic brownie points to earn, no more promotion ladders to climb. One of the last papers he published was on the numerous crises in the latest Somare government. It appeared in Inside Story, a non-refereed online publication. It was titled 'Cranks Emerging', after a quote from an article in the Post-Courier. 'The writer may have meant 'cracks', mused Hank, 'but let the reader allow both wit and insight'.

Donald Denoon remarked that Hank was always concerned with 'outreach' to other researchers, of course, but also to ex-prisoners of war, ex-students, former residents of Papua New Guinea, examiners and writers and supervisors of doctoral theses, Papua New Guinea villagers and many others. He had never met a scholar with such a wide and respectful audience as Hank, whose correspondents included the late Bruce Ruxton, the irascible former president of the RSL, and Rabbie Namaliu, a prime minister of PNG. Bill Gammage ranked Hank among the best-known historians in Australia dealing with crosscultural issues, alongside Henry Reynolds and Geoffrey Blainey. But Hank was unassuming, like Bill, and always stood a pace or two apart from the cult of the academy. He was a highly creative scholar, attuned to the demotic, serious in his commitment and loyalty to his craft but not a solemn person, ponderous; indeed, a certain light touch was one of Hank's endearing attributes in talk and in prose.

Humour was always just below the surface, tactfully deployed to lighten a conversation or defuse a contentious point. 'Struth' was a word I picked up from him. From him, too, I learnt many an Australian colloquial expression that lubricated casual conversation, to show that I was in the know. 'Short of a sheep in the top paddock' was a favourite, along with 'a sandwich short of a picnic' and 'high as a nerd's trousers'. 'An opinion is like an arse: everyone has one', he used to say to me whenever I was down about being unjustly attacked in the media. A politer version of this was, 'Everyone is entitled to have their own opinions, but they are not entitled to have their own facts'.

From the very beginning, Hank combined rigorous scholarship published through conventional scholarly outlets (university presses and academic journals) with shorter articles in newspapers and periodicals. Hank was determined to communicate to a lay audience beyond the academy, and he did that with precision and clarity borne of experience and intimate knowledge of the subject. Whenever he heard me on the radio, he would write encouragingly: 
You spoke well on the Fiji coups on $A B C$ radio. The ANU got a good run. I am sure that there were many things unsaid on air, and you were conscious of that, but we listeners were not, and what we got was considered comment obviously drawn from knowledge and a long perspective.

He did the same with others. Hank 'deserves to be mentioned in all despatches', wrote Norman Davies, the British historian Hank had brought to the division as a visiting fellow. ${ }^{9}$ Ken Inglis is spot-on that Hank was 'an unusually good encourager and critic of work by colleagues, and a sensitive co-operator'.

Alan Gilbert saw Hank as a 'pioneer of multi-media approaches to historical scholarship'. There were two in particular: radio documentary and films. His foray into the former began in collaboration with Tim Bowden of the ABC in the late 1970s when Hank was enlisted as a consultant to the series Taim Bilong Masta: The Australian Involvement with Papua New Guinea. From some 350 hours of original interviews over two years came two dozen 45-minute radio documentaries produced by Bowden and a book by the same title produced by Hank. Collaboration between the two also produced the book P.O.W.:Australians under Nippon, written by Hank. Later Hank worked with the ABC on a radio documentary on one-teacher bush schools because he thought it important to acknowledge the part played in Australian history by those young people sent to the back of beyond to educate bush children, because these had all but disappeared from the scene. The book that came from the series was the deeply evocative With Its Hat about Its Ears: Recollections of the Bush School. 'Even well-disposed listeners and viewers are often unaware of how much original research has gone into what they are listening to and seeing, so artfully has it been blended in', said Ken Inglis. He noted that Hank's 1984 radio feature on Douglas MacArthur and John Curtin 'taught me things I could not find in any printed account of the relationship'. That, from Ken, among Australia's most esteemed historians, is significant praise.

What impressed Bowden most about the book that came from the series was Hank's ability to produce a work of scholarship 'while not alienating the general reader'. For Hank, the oral project led him to ponder 'how people, as individuals and groups, edit and articulate their memories'. All this, Hank said, 'raises many significant theoretical and empirical topics to pursue', including the 'influence of different media on what is said and unsaid, and what audience is reached and what readers and audiences learn'. It pleased Hank that his work on the prisoners of war was used by at least two playwrights and two novelists. David Malouf acknowledged his debt in his prizewinning novel, The Great World. And it led to other radio projects, including one on Australian Volunteers Abroad,

9 Davies is the author of the monumental books The Isles: A History (1999) and Europe: A History (1997), both over 1,000 pages each. 
who went overseas from the early 1950s. Australian War Memorial staff warmly remember Hank for all the interviews he did for them on World War II. He drafted their questionnaires, different for each unit.

Hank was a great believer in making films and using them to disseminate scholarship. Films also had the potential to resolve an ethical dilemma. 'Pacific Islands historians who make films have a chance to return the product of their research to the people they have studied, and in a more accessible form', Hank said. 'It is a moment of pride for people of small language groups to hear their own language coming from the speakers, and to know that those familiar combinations of sounds will be heard in distant places by unknown people'. He even harboured the heretical thought that someday graduate students might be able to submit the results of their research on film! 'The examiners will have to be told about the help of others with editing, photography and sound, but in many of the sciences doctoral research is a group activity, and the publications stemming from the research have joint authors'. Historians, Hank said,

should always be writing, trying to write better, and getting great enjoyment from fine writing by others. I just want historians to use other media, reach more people, communicate better with students, and perhaps in the process produce better history - on pages, sound tapes or film.

I suspect he would add online now as well.

Hank wrote in the ordinary language of intelligent discourse, 'complex thoughts underpinning simple expression, and deep wells of knowledge informing common sense', in Bill Gammage's words. Hank was a real worker, not one of the drones who were sometimes thought by people elsewhere to disproportionately populate the halls of ANU. Donald Denoon captured a common consensus: An exemplary citizen of the scholarly world: avid and perceptive in research, excellent in pioneering new forms of scholarly communication, omnivorous in the range of his interests'. This appreciation is tinged with the regret that 'he was so competent in management that he was increasingly diverted into organisational matters', which he executed 'with humanity and dispatch', regrettably at much cost to his own work.

With Hank, the professional and the personal were always one and the same, Gavan Daws recalled, 'and this made him an exemplary colleague - none better - and a genuinely good citizen of the republic of learning'. More than most, Hank's work expressed in simple readable prose and his many documentaries and innumerable radio interviews were celebrated in countless communities across the nation and region, from Boort to Boroko and beyond, of researchers 
and students, old diggers, rural folk, politicians, bureaucrats, film makers, villagers and ordinary people. That is a fine legacy for the 'boy from Boort'. Em inap, man blong Boort.

\section{NOTE}

Much of the material for this essay comes from Hank Nelson's files in the ANU archives, and for that reason I have seen no need to provide detailed documentation of specific files for the quotes used here, but I am grateful to the people whose words I have used. Jan Nelson provided additional material, and I am enormously grateful to her for her gracious support and friendship over the years. For their comments on a draft, I thank Doug Munro, Vicki Luker, Peter Hempenstall, Stuart Macintyre, Klaus Neumann and fellow contributors Gavan Daws and Bill Gammage. 
This text taken from The Boy from Boort: Remembering Hank Nelson, Edited by Bill Gammage, Brij V. Lal, Gavan Daws, published 2014 by ANU Press, The Australian National University, Canberra, Australia. 